\title{
Pendampingan UMKM dalam Pengelolaan Keuangan Usaha Guna Peningkatan Ekonomi Masyarakat di Distrik Abepura Jayapura
}

\author{
Christina Irwati Tanan \\ Universitas Ottow Geissler Jayapura, Papua \\ christinatanan06@gmail.com \\ Dian Dhamayanti \\ Universitas Ottow Geissler Jayapura, Papua \\ Naskah diterima: 27 Mei 2020 | Naskah disetujui: 15 Juni 2020
}

\begin{abstract}
This research was conducted in the Abepura District of Jayapura in three locations namely: Kotaraja, Abepura, and Kamkey Tanah Hitam towards three micro-enterprise (UMKM) groups consist of food stalls, general kiosks, and noken creative crafts. The objective of this community service program is to increase the engaged community's knowledge and skill of entrepreneurship as well as management of micro-finance. This program is done through the identification of UMKM problems, lectures and discussions, entrepreneurship and micro-finance management assistance, and finished by monitoring and evaluation. Found the results that the UMKM community can utilize the potential of raw materials that have not been utilized maximally through product innovation, but also that they can create simple financial reports for micro-enterprises in order to increase the profitability. This program is expected to be completed by continued working with the government, micro-financing credit fund body, and other stakeholders to overcome capital and other potential problems of UMKM.
\end{abstract}

Keywords: assistance, entrepreneurship, micro-enterprise (UMKM), micro-finance

\begin{abstract}
Abstrak
Penelitian ini dilakukan di Distrik Abepura Jayapura di tiga lokasi yaitu: Kotaraja, Abepura, dan Kamkey Tanah Hitam terhadap tiga kelompok usaha mikro (UMKM) yang terdiri dari warung makan, kios umum, dan kerajinan kreatif noken. Tujuan dari program layanan masyarakat ini adalah untuk meningkatkan pengetahuan dan keterampilan kewirausahaan komunitas yang terlibat serta pengelolaan keuangan mikro. Program ini dilakukan melalui identifikasi masalah UMKM, ceramah dan diskusi, pelatihan kewirausahaan dan manajemen keuangan mikro, dan diselesaikan dengan pemantauan dan evaluasi. Ditemukan hasil bahwa komunitas UMKM dapat memanfaatkan potensi bahan baku yang belum dimanfaatkan secara maksimal melalui inovasi produk, juga bahwa mereka dapat membuat laporan keuangan sederhana untuk usaha mikro untuk meningkatkan profitabilitas. Program ini diharapkan dapat dilanjutkan dengan program pemerintah, lembaga kredit mikro, dan pihak terkait lainnya untuk mengatasi masalah permodalan dan potensi masalah UMKM yang ada.
\end{abstract}

Kata Kunci: keuangan mikro, kewirausahaan, pendampingan, usaha mikro 


\section{Pendahuluan}

Usaha Mikro Kecil Menengah (UMKM) mempunyai potensi dalam perekonomian dan menjadi sumber mata pencaharian untuk memenuhi kebutuhan hidup pelaku usaha. Bahkan UMKM menjadi usaha mandiri yang dikelola oleh masyarakat dengan menciptakan lapangan pekerjaan sehingga UMKM juga memberikan kontribusi pada pertumbuhan ekonomi di suatu daerah (Nugroho dkk, 2020). Keberadaan UMKM bukan saja dilakukan oleh pelaku usaha tetapi juga perlu mendapatkan dukungan dari pihak-pihak lain seperti Pemerintah, sektor swasta, perbankan dan non perbankan dan juga dalam lingkup perguruan tinggi sehingga UMKM dapat bertumbuh menuju usaha yang lebih baik lagi dan berkembang dari waktu ke waktu. Namun belum semua UMKM yang ada mendapatkan pendampingan sesuai dengan masalah yang dihadapi sehingga peran pendampingan UMKM perlu menjadi program yang perlu dilakukan.

Perkembangan UMKM di Kota Jayapura semakin meningkat dari tahun ke tahun yang ditunjukkan dengan meningkatnya jumlah UMKM yang ada dan juga menjadi sumber pendapatan bagi pelaku usaha untuk memenuhi kebutuhan hidup keluarganya. UMKM yang cukup berkembang pesat di Kota Jayapura adalah usaha kuliner berupa warung makan, cafe, rumah makan, usaha aneka kue atau gorengan, dan aneka minuman. Demikian juga penjual pinang, sayur mayur, buahbuahan yang berada di pasar tradisional, juga kios-kios ataupun usaha penyediaan sembako serta kerajinan tangan berupa noken dan kerajinan tangan lainnya.

UMKM hadir karena memberikan peluang yang dimanfaatkan oleh pelaku UMKM dalam menyediakan kebutuhan masyarakat, usaha-usaha yang sedang viral dan memberikan peluang usaha, selera, harganya terjangkau oleh masyarakat umum, adanya konsumen yang menjadi pelanggan setia, tersedianya bahan baku yang membuka peluang usaha, dan sebagainya. Semua ini menjadi peluang terhadap perkembangan usaha yang dilakukan oleh pelaku UMKM. Namun di samping peluang usaha, pelaku UMKM juga menghadapi masalah dalam usaha yang dijalankan seperti masalah modal, kurangnya pelanggan, kurangnya pengetahuan dan kemampuan kewirausahaan, kurangnya pengelolaan keuangan usaha secara baik, tempat usaha berpindah-pindah tempat, kurangnya sarana yang memadai, dan sebagainya. Semua ini tentu menjadi ancaman terhadap perkembangan usahanya. Seperti yang dikemukakan Murdani (2019), faktor pendukung dalam pengembangan masyarakat dalam bidang ekonomi ini meliputi sumber daya alam dan sumber daya manusia yang melimpah. Sedangkan faktor penghambatnya adalah keterbatasan modal, sarana dan prasarana serta partisipasi masyarakat yang rendah. Masalah ini bila tidak mendapat penanganan yang serius akan menjadi masalah serius yang berpengaruh terhadap keberlanjutan usaha yang dilakukan oleh pelaku UMKM sehingga perlu adanya solusi terhadap masalah yang dihadapi.

Demikian juga UMKM di Kota Jayapura menghadapi kendala dalam usaha yang dijalankan, di antaranya kurangnya modal, pemasaran, masih rendahnya pengelolaan keuangan, kurangnya pengetahuan kewirausahaan dalam pengelolaan usahanya. Kebanyakan pelaku UMKM yang ada belum bisa memisahkan antara uang yang digunakan dalam pengelolaan usaha dan uang yang digunakan dalam memenuhi kebutuhan keluarga, sehingga kondisi keuangan usaha yang ada sering disatukan atau digabungkan dengan keuangan keluarga. Bahkan banyak lagi pencatatan ataupun laporan keuangan yang tidak dilakukan karena dianggap merepotkan ataupun karena pelakunya kurang mempunyai kemampuan mencatat ataupun membuat laporan keuangan untuk usaha yang dilakukan, sehingga mereka tidak mengetahui secara pasti berapa pendapatannya perhari atau perbulan. Demikian juga pengeluarannya sehingga semua transaksi hanya diperkirakan dengan 
mengandalkan daya ingat. Artinya, pengetahuan dan kemampuan kewirausahan yang masih kurang karena kebanyakan dalam menjalankan usahanya dengan apa adanya dalam arti yang penting usahanya jalan, sekedar untuk memenuhi kebutuhan hidup. Ada yang menjalankan usaha sudah lama berjalan tetapi tidak berkembang dan tidak ada pertumbuhan seiring waktu atau lamanya usaha yang mereka jalankan. Dan semuanya masalah ini berdampak pada pendapatan mereka.

Untuk mengatasi masalah UMKM, yang terutama dihadapi oleh pelaku usaha mikro di Kota Jayapura, ini maka diperlukan pendampingan terhadap masalah-masalah yang dihadapi agar tidak semakin berdampak pada pendapatan usahanya. Pendampingan yang diberikan berfokus pada pendampingan kewirausahaan dan pengelolaan keuangan usaha mikro berdasarkan identifikasi masalah yang kebanyakan dihadapi oleh pelaku usaha mikro di Distrik Abepura, Kota Jayapura. Pendampingan seperti ini merupakan langkah preventif yang penting untuk dilakukan, karena seperti yang dikemukakan Layyinaturrobaniyah \& Muizu (2017), bahwa banyak kegiatan mikro mengalami kegagalan atau bangkrut dikarenakan tidak mampu mengelola keuangan dengan baik.

\section{Kerangka Teori}

\section{Usaha Mikro Kecil dan Menengah (UMKM)}

Sesuai dengan Undang-Undang Republik Indonesia Nomor 20 Tahun 2008 (www.ojk.go.id, 2017) yang dimaksud dengan Usaha Mikro Kecil dan Menengah (UMKM) yaitu yang diuraikan masing-masing. Usaha Mikro adalah usaha produktif milik orang perorangan dan/atau badan usaha perorangan yang memenuhi kriteria Usaha Mikro sebagaimana diatur dalam Undang-Undang. Kriteria Usaha Mikro adalah sebagai berikut:

a) memiliki kekayaan bersih paling banyak Rp50.000.000,00 (lima puluh juta rupiah) tidak termasuk tanah dan bangunan tempat usaha;atau.

b) memiliki hasil penjualan tahunan paling banyak Rp300.000.000,00 (tiga ratus juta rupiah).

Usaha Kecil adalah usaha ekonomi produktif yang berdiri sendiri, yang dilakukan oleh orang perorangan atau badan usaha yang bukan merupakan anak perusahaan atau bukan cabang perusahaan yang dimiliki, dikuasai, atau menjadi bagian baik langsung maupun tidak langsung dari Usaha Menengah atau Usaha Besar yang memenuhi kriteria Usaha Kecil sebagaimana dimaksud dalam Undang-Undang ini. Kriteria Usaha Kecil adalah sebagai berikut:

a) memiliki kekayaan bersih lebih dari Rp50.000.000,00 (lima puluh juta rupiah) sampai dengan paling banyak Rp500.000.000,00 (lima ratus juta rupiah) tidak termasuk tanah dan bangunan tempat usaha; atau

b) memiliki hasil penjualan tahunan lebih dari Rp300.000.000,00 (tiga ratus juta rupiah) sampai dengan paling banyak Rp2.500.000.000,00 (dua milyar lima ratus juta rupiah).

Usaha Menengah adalah usaha ekonomi produktif yang berdiri sendiri, yang dilakukan oleh orang perorangan atau badan usaha yang bukan merupakan anak perusahaan atau cabang perusahaan yang dimiliki, dikuasai, atau menjadi bagian baik langsung maupun tidak langsung dengan Usaha Kecil atau Usaha Besar dengan jumlah kekayaan bersih atau hasil penjualan tahunan sebagaimana diatur dalam Undang-undang ini. Kriteria Usaha Menengah adalah sebagai berikut:

a) memiliki kekayaan bersih lebih dari Rp500.000.000,00 (lima ratus juta rupiah) sampai dengan paling banyak Rp10.000.000.000,00 (sepuluh milyar rupiah) tidak termasuk tanah dan bangunan tempat usaha; atau 
b) memiliki hasil penjualan tahunan lebih dari $\mathrm{Rp} 2.500 .000 .000,00$ (dua milyar lima ratus juta rupiah) sampai dengan paling banyak Rp50.000.000.000,00 (lima puluh milyar rupiah).

\section{Kewirausahaan}

Entrepreneurship atau kewirausahaan adalah sutu proses dalam mengerjakan sesuatu yang baru atau kreatif dan berbeda (inovatif) yang bermanfaat dalam memberikan nilai lebih. Kewirausahaan berasal dari kata wira dan usaha. Wira berarti pejuang, pahlawan, manusia unggul, teladan, berbudi luhur, gagah berani dan berwatak agung. Usaha adalah perbuatan amal, bekerja, dan berbuat sesuatu. Jadi, wirausaha dapat diartikan sebagai seorang yang berbuat sesuatu (Priscilla, 2019). Dari pengertian ini tentu sangat berkaitan dengan usaha yang dilakukan oleh wirausaha atau entrepreneur dalam mengembangkan usahanya dengan kreatifitas dan inovasinya sehingga usahanya bisa mengalami pertumbuhan yang signifikan dari waktu ke waktu. Sepeti yang dikemukakan oleh Kasali, et al., (2012), seorang entrepreneur adalah seorang yang "moving forward" maju terus ke depan. Usahanya tumbuh dari waktu ke waktu, dari satu kedai menjadi lima, sepuluh, seratus, lalu seribu, dan seterusnya.

Karakteristik kewirausahaan berpengaruh secara nyata dan positif terhadap kompetensi kewirausahaan maupun kinerja usaha (Sari, Suwarsinah, \& M.Baga, 2016). Senada dengan Wardoyo, Rusdianti, \& Purwantini, (2015), konstruksi orientasi kewirausahaan mempengaruhi kinerja bisnis. Dengan demikian, kewirausahaan berpengaruh terhadap kinerja usaha yang berhubungan dengan usaha yang dikelola oleh pelaku UMKM.

\section{Pendapatan}

Menurut Mardiasmo (2018), pendapatan yaitu setiap tambahan kemampuan ekonomis yang diterima atau diperoleh wajib pajak, baik yang berasal dari Indonesia maupun dari luar Indosesia, yang dapat dipakai untuk konsumsi atau untuk menambah kekayaan wajib pajak yang bersangkutan dengan nama dan bentuk apapun. Pengertian pendapatan (Kartikahadi, 2012) adalah penghasilan (income) adalah kenaikan manfaat ekonomi selama satu periode akuntansi dalam bentuk pemasukan atau penambahan asset atau penurunan kewajiban yang mengakibatkan kenaikan ekuitas yang tidak berasal dari kontribusi penanam modal.

Berdasarkan pengertian pendapatan di atas maka pendapatan berhubungan dengan kegiatan usaha ekonomis yang dilakukan oleh masyarakat yang menaikkan asset atau menurunkan kewajiban dan dihasilkan oleh pelaku ekonomi yang juga merupakan wajib pajak.

\section{Pendampingan UMKM}

Pendampingan UMKM perlu dilakukan untuk mengatasi masalah yang dihadapi oleh UMKM yang berkaitan dengan pengetahuan pelaku UMKM yang kurang dalam pengelolaan UMKM. Seperti yang dikemukakan oleh Harventy, Zubaidah, \& Kholmi (2020), dalam konteks pendampingan usaha menengah di Malang, bahwa pengelola atau pemilik Sari Apel Bromo Semeru sebaiknya menyediakan atau memfasilitasi sumber daya manusia yang dirasa mampu mengelola keuangan entitas usaha. Hasil penelitian menunjukkan bahwa pemberdayaan ekonomi melalui pelatihan pelaporan keuangan sederhana dari faktor materi pelatihan, fasilitas, proses dan hasil dari 
pelatihan telah memberikan hasil yang sangat signifikan terhadap dampak usaha UMKM (Hadziq \& Nafis, 2017).

Peningkatan UMK di Distrik Arso Kabupaten Keerom adalah sumber daya manusia (SDM) terkait pendidikan, umur, dan kemampuan dalam mengelola usaha baik keuangan produksi, pemasaran dan sarana dan prasarana (Tanan \& Kocu, 2018) sesuai dengan permasalahan yang dihadapi, seperti upaya yang dapat dilakukan adalah perbaikan manajemen usaha melalui aspek pemasaran, aspek produksi, aspek keuangan serta aspek legalitas usaha dan produk. (Marka, Aziz, \& Alifiana, 2018) . Pendampingan UMKM yang ada baik pendampingan kewirausahaan, pendampingan pengelolaan keuangan, pendampingan pemberdayaan ekonomi dan pendampingan lainnya yang dibutuhkan UMKM dan sasarannya adalah memecahkan masalah yang dihadapi oleh pelaku UMKM.

\section{Pengelolaan Keuangan Usaha Mikro}

Pengelolaan keuangan usaha mikro sangat penting dilakukan dalam usaha yang dilakukan karena berkaitan dengan keberlangsungan usaha secara berkelanjutan karena kebanyakan usaha mikro tidak memiliki laporan keuangan yang memadai sehingga sulit mengetahui pendapatan dan pengeluaran usahanya apalagi keuangan yang ada tidak ada pemisahan antara keuangan untuk usaha dan keuangan keluarga. Usaha yang dijalankan dari waktu ke waktu tidak mengalami perkembangan dan berjalan apa adanya.

Menurut Layyinaturrobaniyah \& Muizu (2017), dalam konteks pelaku usaha kerupuk, hampir semuanya pelaku usaha kerupuk miskin tidak memiliki pencatatan dan pembukuan arus kas yang jelas, terstruktur dan rapih. Mereka juga kesulitan mendapatkan modal karena pendapatan tidak seberapa setiap harinya harus digunakan sebagai modal awal. Berdasarkan masalah yang dihadapi oleh pelaku usaha ini, maka pengelolaan keuangan usaha secara baik perlu dilakukan sehingga usaha yang dikelola oleh pelaku usaha dapat mengatur keuangan usahanya dengan baik baik menyangkut modal usahanya.

Unsur-unsur penting yang perlu diperhatikan dalam pengelolaan keuangan usaha adalah modal usaha, pengelolaan uang usaha, laporan keuangan. Sumber modal usaha terdiri dari modal sendiri atau modal pinjaman, sedangkan jenis modal usaha adalah modal investasi dan modal kerja. Pengelolaan uang usaha yaitu uang usaha adalah sejumlah uang yang digunakan untuk menjalankan usaha terutama untuk modal usaha, uang usaha perlu dipisahkan dengan uang pribadi, penggunaan uang usaha untuk keperluan pribadi harus dicatat atau dihitung sebagai pinjaman dan harus dikembalikan, Uang usaha yang dapat digunakan untuk keperluan pribadi adalah gaji/upah. Laporan keuangan usaha, Unsur-unsur penting laporan keuangan usaha kecil: pembukuan, laporan laba/rugi.

Pembukuan yang dapat dibuat dalam usaha kecil adalah buku catatan pembelian/belanja, buku catatan penjualan/pendapatan, dan buku kas harian. Dokumen penting untuk membuat pembukuan: tanda bukti pembelian/pengeluaran dan tanda bukti penerimaan/pendapatan dalam bentuk kwitansi atau nota. Pelaku usaha mikro perlu memahami setiap unsur-unsur penting dalam keuangan usaha yaitu modal usaha, pengelolaan usaha dan laporan keuangan sehingga dalam pengelolaan keuangan usaha mikro dapat dikelola secara efisien dan efektif.

Untuk melakukan pengelolaan keuangan secara efektif dapat menggunakan neraca (balance sheet), laporan laba rugi dan laporan aliran kas (cash flow statements). Neraca, atau yang juga 
dikenal sebagai pernyataan kekayaaan bersih, adalah bentuk laporan yang menjelaskan nilai semua asset yang dimiliki (sisi aktiva) dan nilai semua kewajiban yang dimiliki dan besarnya modal sendiri (sisi pasiva). Dari neraca tersebut, terlihat berapa besar nilai yang berhasil ditambahkan dari modal yang disetor. Sementara itu laporan laba rugi merupakan laporan yang menunjukkan kinerja pengakumulasian laba dalam kurun waktu tertentu. Nilai laba diperoleh dari pengurangan jumlah pendapatan yang dihsilkan dengan biaya-biaya yang dibutuhkan (Kasali, et al., 2012).

Kelayakan suatu usaha adalah ketika terjadi kondisi di mana hasil yang diperoleh lebih besar dari dana yang diinvestasikan. Semakin besar kelebihan dari dana yang kita investasikan, akan semakin menguntungkan investasi dalam usaha tersebut. Secara matematis, investasi yang menguntungkan tersebut dapat dituliskan sebagai berikut: Keuntungan adalah pendapatan dikurangi total biaya. Pendapatan investasi diperoleh dari perkalian antara jumlah barang yang terjual dengan harga per unit barang tersebut. Sementara itu, total biaya yang digunakan dalam usaha dapat dibagi menjadi dua, biaya tetap (fixed cost) dan biaya tidak tetap (variable cost). Modal kerja merupakan besarnya nilai uang yang dibutuhkan untuk mendukung operasionalisasi suatu bisnis. Tanpa adanya sejumlah uang tersebut, operasionalisasi bisnis akan terganggu, misalnya tidak bisa mendapatkan bahan baku, tidak bisa menyediakan sediaan yang mencukupi, dan tidak tercukupi kas untuk transaksi (Kasali, et al., 2012).

\section{Laporan Keuangan Usaha Mikro}

Laporan keuangan adalah laporan yang berisikan mengenai informasi kinerja keuangan selama periode tertentu serta posisi kekayaan, hutang dan modal perusahaan pada waktu tertentu (Layyinaturrobaniyah \& Muizu, 2017). Menurut J. Fred Weston \& Thomas E. Copeland, laporan keuangan juga melaporkan prestasi historis dari suatu perusahaan dan memberikan dasar, bersama dengan analisis bisnis dan ekonomi, untuk membuat proyeksi dan peramalan untuk masa depan (Sutarno, 2012). Salah satu tujuan dan manfaat laporan keuangan menurut Mahmudi adalah untuk memberikan informasi keuangan sebagai pertimbangan pembuatan keputusan serta untuk pengukuran dan evaluasi kinerja (Tanan \& Duri, 2018). Dengan demikian, laporan keuangan adalah gambaran kondisi keuangan perusahaan pada periode tertentu yang merupakan hasil akhir yaitu kinerja yang dicapai yang digunakan untuk pengambilan keputusan dan pertanggungjawaban.

\section{Metode Pengabdian kepada Masyarakat dan Pemecahan Permasalahan Usaha Mikro}

Kegiatan ini adalah kegiatan Pengabdian Masyarakat yang dilakukan di tingkat Program Studi Ekonomi Pembangunan Universitas Ottow Geissler Jayapura, Papua, yang dalam pelaksanaanya terdiri dari dosen pembimbing dan kelompok PkM oleh mahasiswa Program Studi Ekonomi Pembangunan dan dilaksanakan di bulan Januari, Februari dan Juli 2019. Pelaksanaan kegiatan PkM ini dilaksanakan di tiga tempat: daerah Kotaraja dalam yaitu di warung makan dan kios, di depan Saga Mall Abepura terhadap warung makan dan kelompok usaha noken, dan yang terakhir di warung makan yang berada di kompleks lampu merah Kamkey Tanah Hitam.

Kegiatan usaha mikro yang selama ini dilakukan lebih berfokus pada memenuhi kebutuhan hidup keluarga dan usaha dijalankan apa adanya walaupun usaha sudah berjalan dalan waktu lama. Pengelolaan usaha mikro hanya mengandalkan pengalaman yang mereka dapatkan selama 
menjalankan usahanya sehingga kurangnya pengetahuan dan kemampuan kewirausahaan dalam usaha yang dijalankan.

Dalam pengelolaan keuangan usahanya sering tidak memisahkan antara keuangan usaha dan keluarga. Demikian juga dalam hal pencatatan keuangan tidak dilakukan karena dianggap sulit, buang waktu, dan bahkan merasa kesulitan. Pelaku usaha lebih sering memperkirakan saja dengan mengingat penerimaan dan pengeluarannya sehingga keuntungan usaha, termasuk juga pengeluaran tidak dapat dihitung dengan baik karena kesulitan untuk menghitungnya. Sehingga peningkatan pendapatan dari usaha mereka tidak dapat diketahui dengan akurat. Semuanya ini berdampak pada kurangnya pengembangan usaha dan pendapatan pelaku usaha mikro.

Untuk itu maka sebelum melakukan pendampingan terhadap masalah yang dihadapi, terlebih dahulu diberikan materi-materi dasar sehingga meningkatkan pengetahuan dan kemampuan pelaku usaha mikro dalam berwirausaha dan mengelola keuangan usaha mikro. Dari kegiatan ini mereka dapat mengetahui tujuan dan manfaat dari kegiatan pendampingan yang dilakukan.

\section{Tahapan Kegiatan}

Berdasarkan permasalahan yang dihadapi oleh pelaku usaha mikro di Distrik Abepura adalah masih kurang memahami kewirausahaan dan pengelolaan keuangan usaha mikro, maka metode kegiatan yang pertama kali dilakukan adalah ceramah dengan memberikan materi tentang kewirausahaan dan pengelolaan keuangan serta diskusi tanya jawab. Kemudian untuk lebih meningkatkan kemampuan pengelolaan keuangan usaha mikro dilakukan dengan pendampingan membuat laporan keuangan sederhana, sehingga pelaku usaha dapat membuat laporan keuangan sederhana yaitu laporan rugi laba dan arus kas. Dan selanjutnya yang terakhir adalah monitoring dan evaluasi kegiatan.

Adapun tahapan pelaksanaan kegiatan Pengabdian kepada Masyarakat ini dijalankan sebagai berikut:

1) Identifikasi masalah usaha mikro, yang bertujuan untuk dapat mengetahui masalah yang dihadapi oleh pelaku dengan turun langsung ke tempat usaha.

2) Persiapan bentuk pendampingan sesuai dengan hasil identifikasi masalah. Tujuannya agar pendampingan yang diberikan tepat dan sesuai dengan masalah yang dihadapi oleh usaha mikro.

3) Ceramah dan diskusi dengan tema Kewirausahaan dan Pendampingan Keuangan Usaha Mikro. Tujuannya adalah untuk meningkatkan pengetahuan pelaku usaha mikro terhadap kewirausahaan dan pengelolaan keuangan sesuai dengan kebutuhan dan masalah yang dialami.

4) Pendampingan kewirausahaan dan pengelolaan keuangan usaha mikro. Tujuannya adalah agar pelaku usaha mikro dapat menerapkan pelaksanaan kewirausahaan dan pengelolaan keuangan dengan baik sehingga permasalahan yang dialami sebelumnya dapat terselesaikan.

5) Monitoring dan evaluasi pendampingan, yaitu melihat dampak pendampingan usaha mikro. Tujuannya adalah untuk melihat dampak pendampingan usaha mikro terhadap masalah yang dihadapi oleh pelaku usaha. Secara detail adalah dalam menerapkan kewirausahaan dan mengetahui sejauh mana keberhasilan pendampingan dalam mengatasi masalah yang dihadapi. 


\section{Hasil dan Pembahasan}

Untuk mencapai tujuan pelaksanaan kegiatan Pengabdian kepada Masyarakat, ada 5 (lima) tahapan yang dilakukan dalam kegiatan ini, yaitu:

\section{Identifikasi Masalah Usaha Mikro}

Sebagaimana diketahui, bahwa tujuan kegiatan ini adalah untuk mengetahui masalah yang dihadapi oleh pelaku usaha mikro di tiga wilayah di Distrik Abepura Kota Jayapura. Pelaksanaan kegiatan identifikasi ini dilakukan dengan langsung turun ke tempat usaha mikro dan bertanya langsung kepada pelaku usaha terkait masalah yang dihadapi. Dengan komunikasi yang baik pelaku usaha dapat terbuka menjelaskan masalah yang dihadapi dalam menjalankan usahanya. Berdasarkan hasil identifikasi masalah usaha mikro di Distrik Abepura antara lain: kurangnya pengetahuan pelaku usaha mikro dalam berwirausaha dan pengelolaan keuangan usaha. Di mana dalam menjalankan usahanya apa adanya, untuk memenuhi kebutuhan hidup keluarga, usahanya tidak mengalami perkembangan walaupun sudah dibuka dalam jangka waktu yang lama, tidak ada inovasi produk dan kurang memanfaatkan potensi bahan baku yang ada. Sedangkan dalam pengelolaan keuangan usaha belum dapat ditangani dengan baik, kurangnya pengetahuan dalam pengelolaan keuangan, tidak ada pencatatan keuangan atau laporan keuangan, pelaku usaha belum bisa memisahkan antara uang yang digunakan dalam pengelolaan usaha dan uang yang digunakan dalam kegiatan konsumsi keluarga, sehingga pendapatan dan pengeluaran usaha tidak dapat diketahui dengan pasti, hanya memperkirakan dengan mengingat. Jikapun ada bukti, hanya nota pembelian barang dan sering tidak disimpan dengan baik, data perkembangan pendapatan dan pengeluaran mengalami peningkatan atau penurunan dari waktu ke waktu tidak diketahui dengan pasti hanya perkiraan. Berdasarkan hasil identifikasi masalah ini, maka diketahui bahwa masalah yang dihadapi oleh pelaku usaha dan menjadi prioritas pendampingan adalah terhadap pemahaman kewirausahaan dan pendampingan pengelolaan keuangan. Hasil dari identifikasi masalah ini yang kemudian dilakukan tindak lanjut untuk mempersiapkan bentuk perdampingan dan pelaksanaan pendampingan.

\section{Persiapan Bentuk Pendampingan Usaha Mikro}

Persiapan bentuk pendampingan disesuaikan dengan hasil identifikasi masalah usaha mikro agar pendampingan yang diberikan tepat dan sesuai dengan masalah yang dihadapi. Berdasarkan hasil idenfikasi masalah tersebut di atas, maka bentuk pendampingan yang dipersiapkan, yaitu: 1 . Ceramah Kewirausahaan dan Pengelolaan Keuangan Usaha Mikro, yang dilanjutkan dengan diskusi dan tanya jawab 2. Pendampingan Kewirausahaan dan Pengelolaan Keuangan Usaha Mikro. 3. Monitoring dan evaluasi terhadap peserta kegiatan pendampingan. Dalam persiapan pendampingan ini, semua yang dibutuhkan dalam pendampingan disiapkan baik materi dan modul ceramah dan diskusi, bahkan perlengkapan yang dibutuhkan dalam ceramah dan pendampingan dan monitoring dan evaluasi. 


\section{Ceramah dan Diskusi}

Ceramah dan diskusi Kewirausahaan dan Pendampingan Keuangan Usaha Mikro bertujuan untuk meningkatkan pengetahuan pelaku usaha mikro tentang kewirausahaan dan pengelolaan keuangan usaha. Dalam praktiknya, kegiatan ceramah ini dilakukan di tiga tempat lokasi usaha yaitu di daerah Kotaraja, Abepura, dan Kamkey Tanah Hitam. Pelaksanaan dilakukan langsung di tempat usaha masing-masing sehingga pelaku usaha mikro dapat lebih leluasa berdiskusi dan bertanya tanpa meninggalkan usahanya dengan menyesuaikan waktu yang tepat.

Saat materi ceramah disampaikan, pelaku usaha mikro sangat antusias mendengarkan dan mengikuti penyampaian materi dengan baik. Pada saat kegiatan diskusi, mereka tidak ragu-ragu bertanya tentang kewirausahaan dan pengelolaan keuangan usaha. Secara umum, dalam kegiatan ini diberikan materi tentang kewirausahaan sehingga meningkatkan pengetahuan mereka tentang kewirausahaan dan diharapkan dapat menumbuhkan mental wirausaha dalam mengelola usaha, bukan saja untuk menghidupi keluarga, tetapi juga mendorong agar usaha yang mereka bangun harus mengalami peningkatan dari waktu ke waktu. Demikian juga disampaikan materi pengelolaan keuangan usaha mikro, sehingga mereka memahami pengeloaan keuangan usaha yang baik menyangkut modal usaha, pengelolaan uang usaha, laporan keuangan sederhana untuk usaha mikro. Yang paling sederhana adalah seperti memisahkan keuangan usaha dan keuangan keluarga, membuat laporan keuangan sederhana yaitu laporan laba rugi dan laporan arus kas masuk dan keluar. Materi yang disampaikan selanjutnya dipraktekkan dan dilanjutkan dengan kegiatan pendampingan.

Hasil dari kegiatan ceramah dan diskusi ini adalah meningkatnya pengetahuan pelaku usaha mikro tentang kewirausahaan dan pengelolaan keuangan. Pelaku usaha sudah mengetahui apa yang seharusnya mereka lakukan dalam meningkatkan usahanya, seperti inovasi produk dengan memanfaatkan potensi bahan baku yang tersedia, dapat melihat peluang usaha yang dapat meningkatkan pendapatan mereka. Demikian juga setelah mengetahui pengelolaan uang usaha yaitu dengan cara memisahkan keuangan usaha dan keluarga, membuat laporan keuangan sederhana yaitu laporan laba rugi dan arus kas.

\section{Pendampingan Kewirausahaan dan Pengelolaan Keuangan UMKM}

Tujuan dilakukannya tahapan ini adalah agar pelaku usaha dapat menerapkan secara langsung materi yang mereka dapatkan dalam kegiatan ceramah untuk mengatasi masalah yang dihadapi dalam pengelolaan usahanya. Setelah kegiatan ceramah dilakukan, selanjutnya adalah kegiatan pendampingan kewirausahaan dan pengelolaan keuangan, dimana pelaku usaha mikro mempraktekkan secara langsung tentang kewirausahaan dan pengelolaan keuangan. Praktek kewirausahaan yang dilakukan adalah inovasi produk dan peluang usaha. Dalam kegiatan ini pelaku usaha membuat inovasi produk dengan menambah produk yang mereka tawarkan sesuai dengan kebutuhan dan selera konsumen; seperti warung makan dengan menyediakan variasi menu dengan lebih beragam, seperti menjual menu ayam goreng penyet dengan level pedas dengan mengolah potensi bahan baku yang tersedia yaitu cabai. Demikian juga aneka gorengan yang dapat diinovasikan dalam bentuk pisang keju dan pisang lumpur, keladi tumbuk, dan lain-lain. Demikian juga untuk minuman panas dan dingin. Adapun untuk kios, inovasi produk ini dapat dilakukan , dengan menambah produk yang dibutuhkan konsumen, sedangkan untuk usaha noken dengan 
membuat motif yang bervariasi sesuai selera konsumen, gantungan kunci motif assesoris papua seperti tifa, honai, dan batik khas Papua. Dalam kegiatan ini, diajarkan bahwa mereka harus menyesuaikan dengan modal usaha yang dimiliki karena terbatasnya modal usaha. Demikian juga pengolahan keuangan, pelaku usaha sudah dapat dalam memisahkan keuangan usaha dan keuangan keluarga, dapat membuat laporan keuangan sederhana untuk usaha yang mereka kelola yaitu membuat laporan rugi laba dan laporan arus kas.

\section{Monitoring dan Evaluasi Pendampingan}

Monitoring dan evaluasi terhadap dampak pendampingan usaha mikro bertujuan untuk melihat secara langsung dampak dari kegiatan pendampingan yang sudah dilakukan. Dan terus melatih dan membiasakan pelaku usaha mikro dalam menerapkan kewirausahaan dan pengelolaan keuangan secara tepat dan berkelanjutan. Setelah kegiatan pendampingan ini dilakukan, maka selanjutnya proses monitoring dan evaluasi dilakukan untuk melihat keefektifan penerapan pendampingan ini. Dari hasil monitoring dan evaluasi ini, diperoleh saran bahwa dalam menjalankan usahanya, pelaku usaha mikro mulai terbiasa menerapkan pengelolaan keuangan sederhana dengan baik. Demikian juga adanya pengembangan usaha mereka dengan menambah jenis produk yang dihasilkan dengan melihat peluag-peluang usaha yang sudah dapat dilakukan oleh pelaku usaha mikro. Seperti warung makan, di samping menambah variasi menu makanan seperti variasi ayam goreng juga dengan menyediakan ayam goreng penyet dengan level pedas yang diminta konsumen, aneka gorengan juga menambah variasi aneka minuman panas dan juga dingin. Dan dalam menawarkan produknya ada kelompok usaha yang sudah dapat melakukan penjualan secara online tidak terbatas pada konsumen yang makan di warung makan akan tetapi juga menyediakan perbelian secara online. Demikian juga dengan usaha ekonomi kreatif noken, mereka bisa menciptakan dan menambah variasi model noken sesuai selera pasar, juga pernak pernik yang menarik seperti gantungan kunci dengan asesoris tifa, honai dan juga variasi dengan motif batik Papua. Kelompok usaha kios ini juga sudah dapat menjual barang-barang dibutuhkan oleh konsumen dengan mengelola modal usaha yang dikelola dengan baik untuk melengkapi barangbarang yang dijual dan dibutuhkan oleh konsumen.

Hasil dari kegiatan ini adalah meningkatnya pengetahuan dan kemampuan pelaku usaha mikro tentang kewirausahaan dan pengelolaan keuangan. Demikian juga dalam melihat potensi dan peluang untuk meningkatkan pendapatan usahanya, melalui kegiatan ini, dapat dipecahkan masalah yang sering mereka hadapi. Utamanya adalah dilihat dari dampak pendampingan terhadap masalah usaha mikro, sehingga dapat diketahui peningkatan pendapatan usaha maupun efisien pengeluaran mereka.

Berdasarkan hasil kegiatan pengabdian kepada masyarakat di Distrik Abepura maka tingkat pemahaman pelaku usaha mikro yang mengikuti kegiatan ini meningkat, yaitu tentang kewirausahaan dan pengelolaan keuangan usaha mikro yaitu: pengelolaan keuangan usaha dengan memisahkan keuangan usaha dan keuangan keluarga, dapat membuat laporan laba rugi dan laporan arus kas baik kas masuk maupun kas keluar.

Kegiatan pendampingan ini dapat berjalan dengan baik karena adanya antusias dari pelaku usaha mengikuti kegiatan ini sehingga mereka dapat memahami kewirausahaan dan pengelolaan keuangan usaha mikro dengan baik. Demikian juga keinginan dan kemauan pelaku usaha untuk 
membuat laporan keuangan baik laporan laba rugi dan laporan arus kas. Antusiasme mereka tunjukkan juga dalam kegiatan diskusi dan tanya jawab dengan banyaknya pertanyaan yang diajukan. Di samping itu terdapat juga kendala dalam kegiatan pengabdian kepada masyarakat yaitu karena kurangnya pengetahuan dan kemampuan pelaku usaha mikro tentang kewirausahaan dan pengelolaan keuangan, maka pengabdi berusaha disiplin dengan membiasakan menerapkan laporan keuangan usaha untuk usaha yang dijalankan.

\section{Kesimpulan}

Berdasarkan hasil monitoring dan evaluasi pendampingan kewirausahaan dan pengelolaan keuangan usaha mikro di Distrik Abepura, Kota Jayapura, Papua, kegiatan pendampingan dapat berjalan dengan baik dan mendapat sambutan yang baik dari pelaku usaha mikro. Kegiatan ini dapat disimpulkan berhasil, mulai dari semua tahap pelaksanaan kegiatan yang diikuti pelaku usaha dengan adanya antusiasme dan respon positif pelaku usaha dalam mengikuti kegiatan pendampingan. Adanya kesesuaian materi dengan masalah yang dihadapi untuk meningkatkan pemahaman kewirausahaan dan pengelolaan keuangan usaha mikro, peserta pelaku usaha sudah dapat berinovasi atas produk yang dihasilkan dan memanfaatkan potensi peluang usaha seperti pemanfaatan bahan baku, sebagian pelaku usaha dapat melakukan penjualan online, dapat membuat laporan keuangan sederhana yaitu laporan laba rugi dan aliran kas masuk dan keluar, serta dapat memahami dan merasakan manfaat kegiatan pendampingan. Pada akhirnya, dampak dari kegiatan pendampingan ini secara praktis dapat meningkatkan pendapatan pelaku usaha mikro di Distrik Abepura.

Kegiatan pendampingan ini diharapkan dapat dilanjutkan dengan upaya menjalin kerja sama dengan pemerintah, sektor swasta bahkan lembaga kredit mikro untuk mengatasi masalah modal, dan berbagai permasalahan yang mungkin muncul kemudian.

\section{Pernyataan}

Ucapan terima kasih disampaikan kepada semua pihak yang telah membantu sehingga pelaksanaan pengabdian kepada masyarakat di Kelurahan Distrik Abepura dapat berjalan dengan baik. Juga kepada Kepala Kantor Distrik Abepura yang telah memberikan ijin pelaksanaan kegiatan Pendampingan Usaha Mikro dan juga LPPM Universitas Ottow Geissler Papua serta anggota tim PKM Ekonomi Pembangunan yang memberikan dukungan berarti.

\section{Referensi}

Hadziq, M., \& Nafis, M. (2017). Implikasi Pendampingan Mitra Usaha Kecil Menengah (Studi Pendekatan Melalui Pelatihan Laporan Keuangan Sederhana). Jurnal Middle East and Islamic Studies, 396-409.

Harventy, G., Zubaidah, S., \& Kholmi, M. (2020). Pendampingan Penyusunan Pelaporan keuangan Pada Kelompok Usaha Kecil dan Menengah Brosem Semeru. Jurnal Pengabdian dan Peningkatan Mutu Masyarakat, 60-74.

Kartikahadi. (2012). eprints.polsri.ac.id. Retrieved from eprints.polsri.ac.id: eprints.polsri.ac.id/3729/3/BAB\%2011l.pdf 
Kasali, R., Nasution, A. H., R.Purnomo, B., Ciptarahayu, A., Larso, D., Mirzanti, I. R., et al. (2012). Modul Kewirausahaan Untuk Program Strata 1. In Modul Kewirausahaan Untuk Program Strata 1. Jakarta Selatan: Penerbit Hikmah (PT Mizan Publika).

Layyinaturrobaniyah, \& Muizu, W. O. (2017). Pendampingan Pengelolaan Keuangan Usaha Mikro Di Desa Purwadadi Barat Dan Pasirbungur Kabupaten Subang. Pekbis Jurnal, 91-103.

Mardiasmo. (2018). Perpajakan Edisi Terbaru 2018. Yogyakarta: Penerbit Andi.

Marka, M. M., Aziz, N., \& Alifiana, M. A. (2018). Pengembangan UMKM Madumongso Melalui Manajemen Usaha Dan Legalitas Usaha. ABDIMASLP2M Universitas Negeri Semarang as the application of science communication technology, sports, culture, and arts in empowering the community.

Murdani, S. W. (2019). Pengembangan Ekonomi Masyarakat Melalui Pemberdayaan Usaha Mikro Kecil dan Menengah (Studi di Kelurahan Kandri Kecamatan Gunungpati Kota Semarang). ABDIMAS Jurnal Pengabdian Kepada Masyarakat, 152-157.

Nugroho, L., Hidayah, N., Ali, A., \& Badawi, A. (2020). E-Commerce to Improve Homemaker Productivity (Women Entrepreneur Empowerment at Meruya Utara, Kembangan District, West Jakarta, Indonesia). Amalee: Indonesian Journal of Community Research and Engagement, 1(1), 13-24. https://doi.org/10.37680/amalee.v1i01.166

Pricillia, D. (2019). Kewirausahaan, diakses dari https://bbs.binus.ac.id/businesscreation/2019/04/kewirausahaan/ pada 5 Juni 2020.

Sari, N. M., Suwarsinah, H. K., \& M.Baga, L. (2016). Pengaruh Karakteristik Kewirausahaan Terhadap Kinerja Usaha Mikro, Kecil dan Menengah (UMKM) Gula Aren di Kabupaten Lombok Barat. Jurnal Penyuluhan.

Sukirno, S. (2008). repository.uin-suska.ac.id. Retrieved from repository.uin-suska.ac.id: repository.uin-suska.ac.id/6564/4/BAB\%2011l.pdf

Sutarno. (2012). Serba-serbi Manajemen Bisnis. Yogyakarta: Graha Ilmu.

Tanan, C. I., \& Kocu, E. A. (2018). Analisis Modal Kredit Usaha Rakyat Terhadap Pendapatan Pelaku UMK Di Distrik Arso Kabupaten Keerom (Studi Kasus Bank BRI KCP, Arso II). Jurnal Fessospol USTJ Jayapura, 14-24.

Tanan, C., \& Duri, J. (2018). Analisis Rasio Untuk Pengukuran Kinerja Keuangan dan Evaluasi Kinerja Keuangan Pemerintah (Studi Kasus Pemerintah Kota Jayapura). FUTURE:Jurnal Manajemen dan Akuntansi UNIYAP, 91-101.

Wardoyo, P., Rusdianti, E., \& Purwantini, S. (2015). Pengaruh Orientasi Kerirausahaan Terhadap Strategi Usaha dan Kinerja Bisnis UMKM Di Desa Ujung-Ujung, Kec.Pabelan,Kab Semarang. Journal Proceeding.

www.ojk.go.id. (2017). Undang-Undang Nomor 20 Tahun 2008 Tentang Usaha Mikro, Kecil, dan Menengah, diakses dari https://www.ojk.go.id/sustainable-finance/id/peraturan/undangundang/Pages/Undang-Undang-Republik-Indonesia-Nomor-20-Tahun-2008-Tentang-UsahaMikro,-Kecil,-dan-Menengah.aspx pada 3 Juni 2020. 